\title{
Periodic mass-bleaching and elevated sea temperatures: bleaching of outer reef slope communities in Moorea, French Polynesia
}

\author{
O. Hoegh-Guldberg ${ }^{1}$, B. Salvat ${ }^{2,3}$ \\ ${ }^{1}$ School of Biological Sciences, Building A08, University of Sydney, New South Wales 2006, Australia \\ ${ }^{2}$ EPHE-CNRS, URA 1453, Université de Perpignan, F-66860 Perpignan, France \\ ${ }^{3}$ CRIOBE, Centre de Recherches Insulaires, BP 1013, Moorea, French Polynesia
}

\begin{abstract}
Mass-bleaching events (in which corals and other symbiotic invertebrates lose their zooxanthellae) have been occurring every 3 to 4 yr since 1979. The last report of widespread mass-bleaching in the Pacific (which included bleaching around French Polynesia) was in February-April 1991. This paper reports on mass-bleaching along the outer reef slope of Moorea, French Polynesia, in April 1994. Mass-bleaching was extensive at all sites visited, with corals being bleached down to $25 \mathrm{~m}$. Colour loss by corals was due to low areal densities of zooxanthellae and the percentage of live coral affected ranged between 39.6 ( $\pm 7.12, \mathrm{SEM}$ ) (NW sites) and 72.4 ( $\pm 7.11, \mathrm{SEM}$ ) (NE sites). Bleaching also varied as a function of depth and included a wide range of species. Acropora spp. showed the most severe bleaching $(89.0$ to $100 \%$ of all colonies completely bleached) and Porites spp. showed the least amount of bleaching (12.9 to $42.5 \%$ of all colonies partly bleached). Pocillopora spp. showed intermediate bleaching ( 73.9 to $92.1 \%$ of all colonies either partly or completely bleached). The results of this report indicate that current bleaching is on a scale equal to that of the 1991 bleaching event. Temperatures recorded hourly at $14 \mathrm{~m}$ of the outer reef slope from July 1991 to August 1994 (and those from satellite sea surface temperature readings) indicate unusually warm sea temperatures in March 1994, which were approximately $1.0^{\circ} \mathrm{C}$ higher than the highest temperatures recorded in 1992 and 1993 , years in which bleaching on a massive scale did not occur. The appearance of warmer temperatures preceded the onset of bleaching by 2 to $3 \mathrm{wk}$, which strongly confirms the hypothesis that positive thermal anomalies are responsible for recent bleaching events in the Central and Western Pacific.
\end{abstract}

KEY WORDS: Coral - Mass-bleaching $\cdot$ Zooxanthellae $\cdot$ Temperature Stress $\cdot$ Moorea $\cdot$ Tahiti French Polynesia

\section{INTRODUCTION}

The mass-bleaching of coral reefs results in corals and other symbiotic invertebrates losing their characteristic brown colour ('bleach'; Yonge \& Nichols 1931). Since 1979, major mass-bleaching events have been reported approximately every 3 to $4 \mathrm{yr}$ (for review, see Williams \& Bunkley-Williams 1990), and have been accompanied, in most cases, by a significant mortality of bleached invertebrates (Harriot 1985, Oliver 1985 , Glynn 1988, 1993, Brown \& Suharsono 1990, Salvat 1991, 1992b). Previous studies have shown that bleaching is due either to the disappearance of zooxanthellae from the tissues of the host or to the loss of photosynthetic pigments by resident zooxanthellae (Hoegh-
Guldberg \& Smith 1988, 1989, Reese et al. 1988). In most mass-bleaching events investigated so far, however, loss of zooxanthellae has been identified as the major reason for colour loss during the bleaching of corals (Hoegh-Guldberg \& Smith 1988, 1989, Gates 1990, Glynn \& D'Croz 1990, Hayes \& Bush 1990, Glynn et al. 1993). The outward movement of zooxanthellae has been shown to be due to the detachment and expulsion of host endodermal cells that enclose zooxanthellae in laboratory experiments (Gates et al. 1992) although how universal this observation is for corals undergoing bleaching in the field remains to be determined.

Corals normally show low rates of loss of zooxanthellae to the water column (Hoegh-Guldberg et al. 
1987). A range of physical conditions, however, provoke greater rates of loss from symbiotic hosts (Yonge \& Nichols 1931, Hoegh-Guldberg \& Smith 1989, Glynn \& D'Croz 1990, Lesser et al. 1990, Glynn et al. 1993). Experimental manipulations of PAR (photosynthetically active radiation) or ultraviolet light (Vaughan 1914, Yonge \& Nichols 1931, Hoegh-Guldberg \& Smith 1989, Gleason \& Wellington 1993) and/or temperature (Jokiel \& Coles 1974, 1977, Coles \& Jokiel 1978, Hoegh-Guldberg \& Smith 1989, Gates et al. 1992, Glynn et al. 1993) produce characteristics in corals similar to those of bleached coral collected in the field. Other factors such as reduced salinity may cause colour loss but do not cause corals to lose zooxanthellae to the extent seen during mass-bleaching events (Hoegh-Guldberg \& Smith 1989). Field studies have also correlated changes in environmental variables with mass-bleaching (for review, see Glynn 1993). So far, the most consistent factor associating with mass-bleaching events has been elevated sea temperatures (Glynn 1984, 1991, Lasker et al. 1984. Gates 1990, Salvat 1991, Glynn \& Colgan 1992), and recent evidence (e.g. Coffroth et al. 1990, Glynn 1993, Goreau \& Hayes 1994) has strengthened the connection between elevated seawater temperatures and mass-bleaching events (but see Atwood et al. 1992).

The scale of the disturbance to coral reefs, and its apparent appearance at the beginning of last decade, has made mass-bleaching a concern for both scientists and policy makers alike (Roberts 1987, 1988, Goreau 1992, Salvat 1992a, Sebens 1994). The last report of widespread mass-bleaching was in February-April 1991, which also involved large areas of French Polynesia. Beginning in February 1994, however, reports of mass-bleaching were received from divers, scientists and tour operators in areas of the central and western Pacific (Cook Islands, Western Samoa, American Samoa, French Polynesia; L. Goldsworthy \& E. Mealy, Greenpeace International, pers. comm.). These preliminary accounts indicated visual estimates of bleaching that ranged from 50 to $100 \%$ of hard corals in these areas and suggested that mass-bleaching was on a scale similar to that of the 1991 event.

This study reports on the extent of mass-bleaching on the outer reef slope of Moorea in French Polynesia in April 1994. The aim of this study was to determine the size and extent of mass-bleaching, and to compare it to previous mass-bleaching events in French Polynesia (Salvat 1991, 1992b, Gleason 1993). The findings of this study are unambiguous. Mass-bleaching began to occur in French Polynesia during mid to late February, and was severe at several sites around French Polynesia by March-April 1994. Comparison to data collected by Salvat (1991, 1992b) and Gleason (1993) during the mass-bleaching of Moorean reefs in 1991 indicates that the current bleaching event is at least as severe as that reported during April 1991. Unusually high water temperatures recorded during 1994 (up to $+1.0^{\circ} \mathrm{C}$, from on-site measurement and satellite data) indicate that warmer than normal sea temperatures were associated with the advent of the current mass-bleaching event.

\section{MATERIALS AND METHODS}

Four sites were examined along the northern reef slope of Moorea (Fig. 1A). In addition to measurements to assess the intensity and extent of mass-bleaching, the connection between elevated sea temperature and the advent of mass-bleaching was explored using data from continuous in situ temperature measurements along the outer reef slope of Moorea.

Temperature measurements. Temperatures were recorded during dives at all sites. In addition, temperatures were obtained from a monitoring project at $14 \mathrm{~m}$ at Site D (Tiahura, D in Fig. 1A) where measurements were taken every hour continuously using waterproof thermocouples (accuracy $\pm 0.05^{\circ} \mathrm{C}$ ) and in situ data loggers. Regional trends in sea temperature were also acquired from satellite data (monthy editions of Climate Diagnostics Bulletin, Climate Analysis Center, U.S. Dept of Commerce, National Oceanic and Atmospheric Administration, Washington, DC, USA).

Transect data. The extent of bleaching was examined at the 4 sites. At each of 3 sites (NW, Middle and $\mathrm{NE}$ ), three $30 \mathrm{~m}$ transect lines were established (transects began at $5 \mathrm{~m}$ and ended at 13 to $15 \mathrm{~m}$ depth), and photographs were taken of corals growing on either side of the transect line. Bleached corals are easily discernible from unbleached corals as shown in Fig. 1B (sample photograph from transect series). Coral colonies growing within $1.5 \mathrm{~m}$ on either side of the transect line were analysed for evidence of bleaching. Corals greater than $5 \mathrm{~cm}$ in size were identified, counted and assigned to 1 of 3 categories: completely bleached; partly bleached; and no evidence of bleaching. Proportions of the total number of living colonies that were bleached were calculated from these data. Selected subsets of data were scored by a second person (S. Dove) and were found to confirm the results of the primary analysis.

Four transect lines (length: $100 \mathrm{~m}$ ) were also monitored in situ (in a separate study) during dives at the Tiahura outer reef slope (Site D, Fig. 1A) by SCUBA divers from the CRIOBE laboratory, in Moorea. These transects were located at 12 to $16 \mathrm{~m}$ depth. Corals were identified to genus and classified as (1) normal-looking, (2) bleached (partly or totally) or (3) dead. The latter case was detected by noting the presence of tufting algal growths across otherwise white coral skeletons. 
Measurements of coral biomass parameters. The condition of tissue associated with bleached corals was examined and compared to that of previous
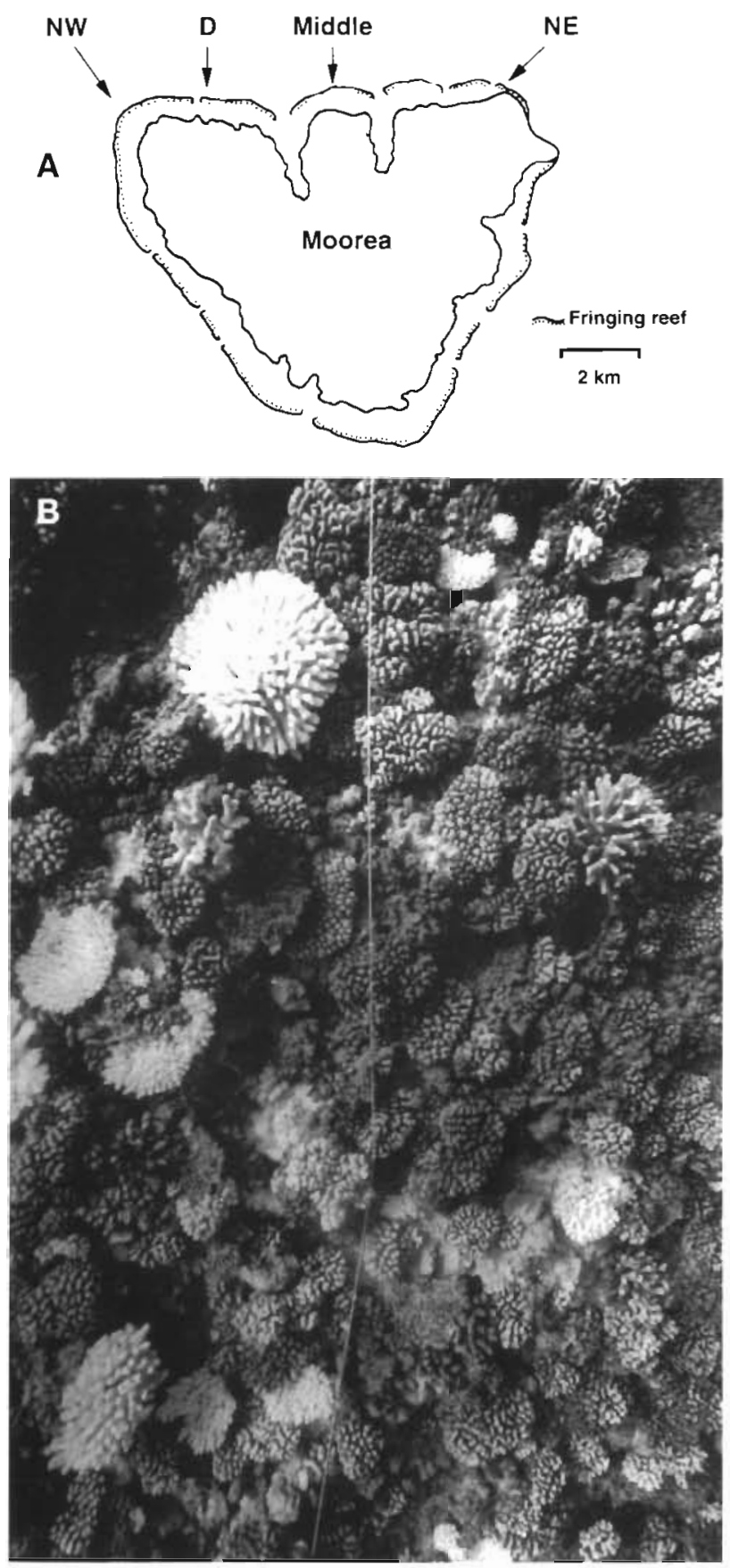

Fig. 1. (A) Location of study sites off the north coast of Moorea, French Polynesia. Photographic transect sites: NW = northwest site, Middle = middle site, $\mathrm{NE}=$ northeast site . Direct censusing was carried out by divers at Site D. Map adapted from Gleason (1993). (B) Outer slope community (15 $\mathrm{m}$ depth) along one of the transects at the Middle site off the north coast of Moorea bleaching events. Several biomass parameters were examined in corals growing at 3 depths $(7,13$ and $23 \mathrm{~m}$ ) at Site D (Fig. 1A). Two branches were removed from each of 4 colonies of the corals Pocillopora verrucosa, Acropora samoensis and $A$. subulata growing at each of the 3 depths. Samples were taken immediately to the Gump Biological Station, Moorea, and were fixed in $5 \%$ formalin in seawater for $24 \mathrm{~h}$. After measuring the surface area of each colony using the foil method of Marsh (1970), the samples were decalcified in $5 \% \mathrm{HCl}$. Following decalcification, tissue samples were rinsed in distilled water, blotted dry and weighed using a Sartorius balance (= wet weight). Samples were then minced, mixed and a small portion of the sample was separated and weighed. This subsample was homogenized in filtered seawater, and the number of zooxanthellae counted. The rest of the minced sample was dried for $10 \mathrm{~d}$ at $60^{\circ} \mathrm{C}$ in a ventilated oven, and reweighed (= dry weight). The number of zooxanthellae was standardized to (1) surface area, (2) total wet weight, and (3) total dry weight.

Statistical analysis. Transect data were analysed using ANOVA (GMAV5, A. J. Underwood \& M. G. Chapman, University of Sydney) after verifying that data were homoscedastic (Cochran's test), and ensuring that immediately adjacent quadrats were never analyzed within the same analysis in order to ensure data independence. Data were transformed using the arcsin function in cases where results were proportions or percentages.

\section{RESULTS}

When the research team arrived at the first transect site (NE), bleached corals were conspicuous from the surface as a white haze across the submerged reef substratum. This was despite the fact that the reef substratum was approximately 15 to $20 \mathrm{~m}$ below the boat. Subsequent inspection at all sites along the outer reef slope off the northern coast of Moorea revealed clear signs of mass-bleaching from the surface.

\section{Water column temperatures}

Temperatures recorded at the surface and at depths down to $20 \mathrm{~m}$ during dives in this study ranged between 29.5 and $30^{\circ} \mathrm{C}$, backing up impressions from local scientists, divers and fishermen that the sea around Moorea was exceptionally warm for this period of the year. Monthly mean temperatures (from hourly measurements of temperature over each month from July 1991 to August 1994) at Site D (Fig. 2A) 

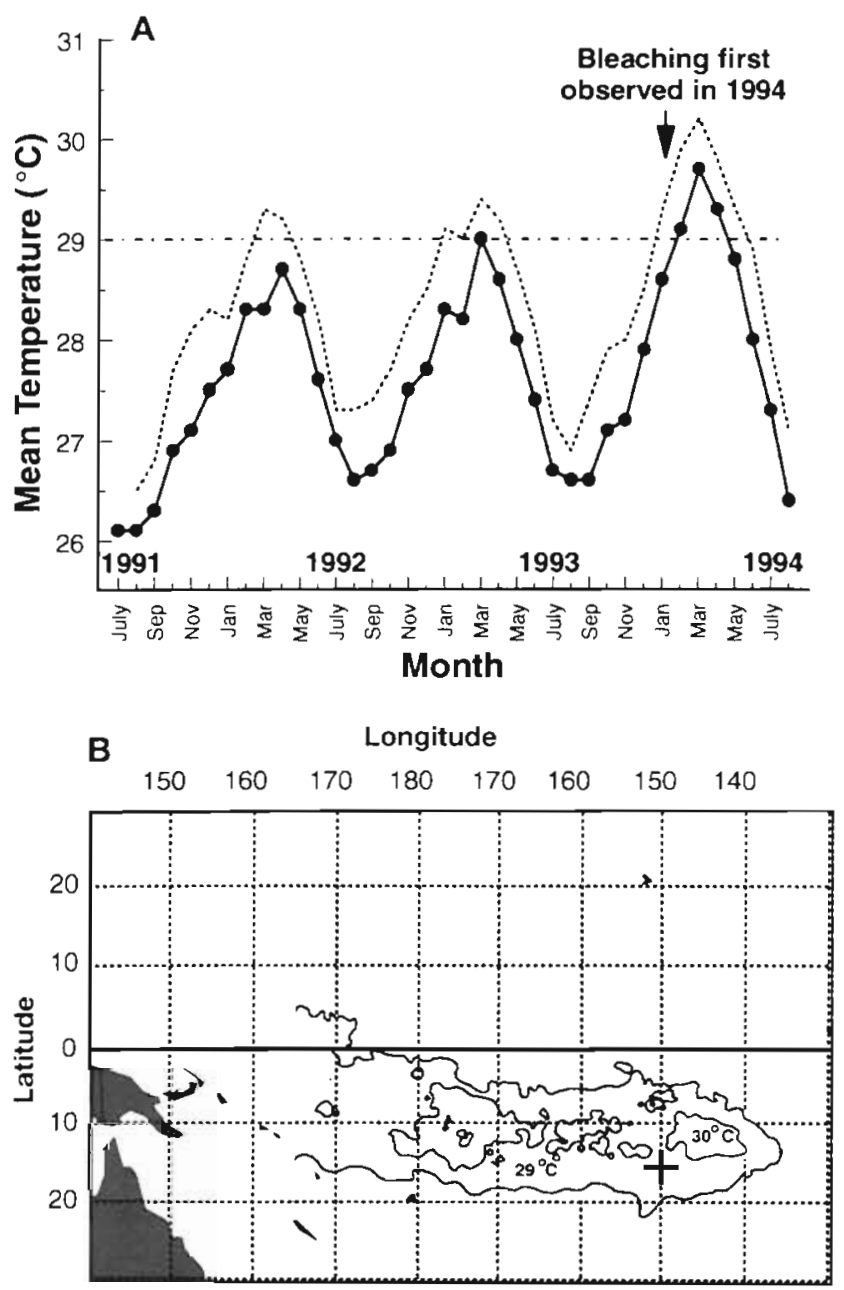

Fig. 2. (A) Temperatures measured at $14 \mathrm{~m}$ depth at Site D (see Fig. 1A) from July 1991 to August 1994. Shown are monthly means from temperature data that were measured every hour using in situ data loggers. Points indicate monthly means, dotted line indicates maximum temperatures for each month and horizontal dashed line represents $29^{\circ} \mathrm{C}$. (B) Isotherms ( 29 and $30^{\circ} \mathrm{C}$ only) for the Central and Western Pacific for the week ending 26 April 1994. Data were traced from satellite data (Climate Analysis Center, U.S. Dept of Commerce, National Oceanic and Atmospheric Administration, Washington, DC, USA). The cross indicates the approximate position of French Polynesia

show an increase in water column temperature that began in January 1994 and reached levels in March that were 0.9 and $0.8^{\circ} \mathrm{C}$ higher than temperatures recorded in March 1992 and 1993 (both years in which bleaching on a massive scale did not occur). It is noteworthy that mild bleaching of a few colonies did occur in 1993 (B. Salvat pers. obs.). The first reports of bleaching (February 1994; L. Goldsworthy \& E. Meally pers. comm.) appeared 2 to $4 \mathrm{wk}$ after the beginning of the temperature increase. Satellite maps of sea sur- face temperature (SST; example in Fig. 2B) show additional evidence of unusually high water temperatures $\left(30^{\circ} \mathrm{C}\right)$ being present in the Central Pacific during April 1994, as compared to previous years (data not shown but available in the NOAA Climate Diagnostics Bulletins).

\section{Photographic transects}

Species composition of study sites

Analysis of the total number of colonies of each type of coral at the NW, Middle and NE sites revealed a significant interaction $(p<0.0001)$ between site and category (genus) of coral (e.g. Acropora spp. versus Pocillopora spp.; Fig. 3). The NW site was relatively impoverished with respect to some coral categories (Pocillopora spp., Acropora spp.; Fig. 3A, B), while being relatively richer in some other coral categories (e.g. Porites spp.; Fig. 3C). The 3 sites did not differ with respect to the number of fungiids (Fig. 3D) or the presence of encrusting or massive corals (Fig. 3E). The mean number of fungiids did, however, increase from NW to NE. Species composition derived from visual estimates made at Site D (Table 1) confirmed the community trends found across the north coast of Moorea (Fig. 3A to E).

Extent of mass-bleaching on the outer reef slope of Moorea

Data representing the percentage of all coral colonies bleached from non-contiguous quadrats were used in order to reduce the possibility of interdependence between data. To achieve this, every second quadrat was eliminated from the analysis. The results of the analysis of variance of the percentage of all coral colonies bleached revealed a significant interaction $(p<0.001)$ between the field site and depth at which the samples were collected. In the case of data concerning Pocillopora spp. alone, variation with depth and site was significant $(p<0.001)$ while the interaction between site and coral category was not significant ( $p>0.05)$.

Variation between sites. Subsequent analysis [Student-Newman-Keuls (SNK) tests] revealed significantly lower proportions of bleached corals at the NW site than the other 2 sites ( $\mathrm{p}<0.05$; cf. $39.6 \%$ versus $67.1 \%$ and $72.4 \%$; see Fig. 4 ). This trend also held for Pocillopora spp., with a significantly lower proportion of colonies being affected at the NW site $(p<0.01$, Fig. 5A). Visual estimates of bleaching from Site D confirmed the trends found at the other 3 sites (Table 2). 
A Pocillopora spp.

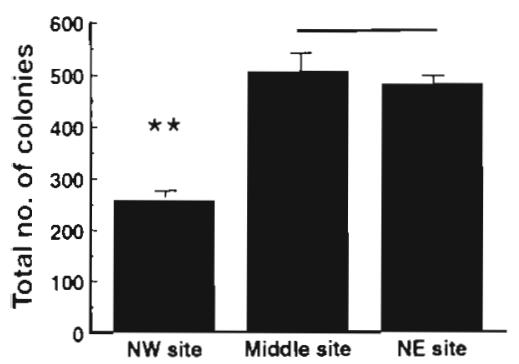

B Acroporaspp.

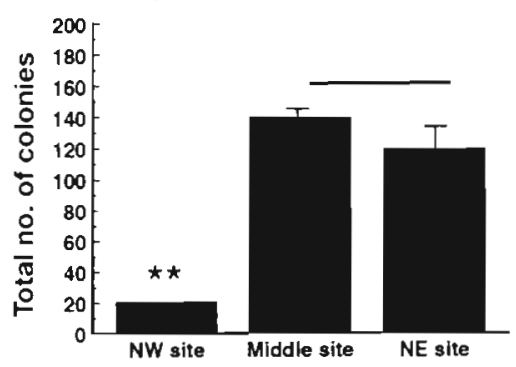

C Porites spp.

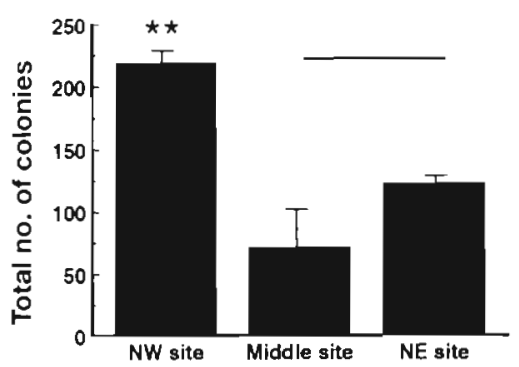

D Fungiids

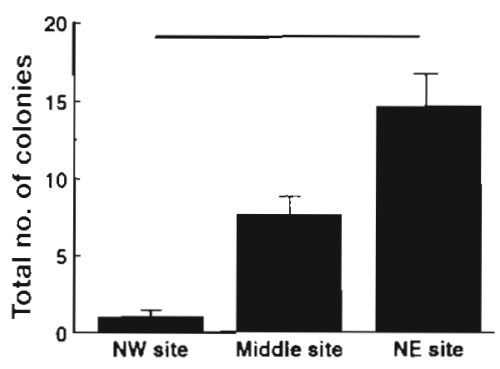

E Other species

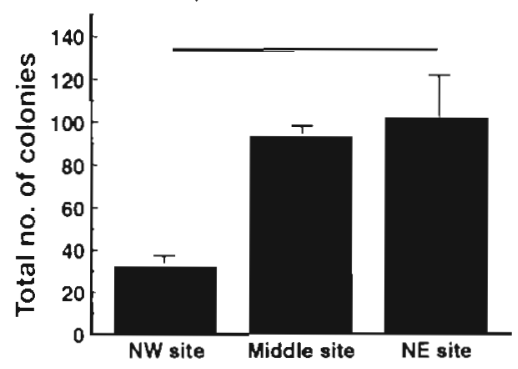

Fig. 3. Total number of colonies of corals in 5 basic categories from 3 sites along the north coast of Moorea. The approximate area examined along each transect was $90 \mathrm{~m}^{2}$ Shown are means and standard errors of the mean $(n=3)$. Lines connect means that are not statistically different; significant differences indicated by $\cdots(p<0.01)$ dependent fashion. The NW site had significantly greater numbers of bleached corals at shallower versus deeper sites ( $<<0.05$; Fig. 4A). There was no such trend at the Middle site, and the trend was reversed at the NE site, with significantly more corals bleached at the deeper site $(p<0.05)$.

The variation in bleaching with depth was also investigated for Pocillopora spp alone. In this case, significantly greater numbers of colonies showed signs of bleaching at the deeper sites ( $p<0.01$; Fig. 5B, C).

\section{Species-dependent susceptibility to bleaching}

The extent to which bleaching occurred varied between different categories of coral (Fig. 6; Tables 2 \& $3)$. The relative order of susceptibility was: Acropora spp. and fungiids $(89.0$ to $100 \%$ of colonies mostly completely bleached), Pocillopora spp. (73.9 to 92.1\% partly or completely bleached), Montastrea, Montipora and Goniastrea spp. $(20$ to $50 \%$ mostly partly bleached), Porites spp. (12.9 to $42.5 \%$ mostly partly bleached). The order of susceptibility was similar to that seen with data collected in situ from Site D by CRIOBE SCUBA divers (Table 2 ).
Mortality was low, with less than $1 \%$ of coral colonies having recently died (detected as white skeletons with beginning growths of algae).

Variation between depths. The percentage of corals bleached varied significantly with depth in a site-

Table 1 Coral species composition (percentage of species within each category) of 4 sites along the outer reef slope of the north coast of Moorea. Shown are mean and standard error of the mean, with the number of transects indicated in parentheses. Data were collected using photographic transects except in the case of Site D, where measurements were made by visual census on site

\begin{tabular}{|lrrrr|}
\hline & NW site & \multicolumn{1}{c}{$\begin{array}{c}\text { Site D } \\
\text { (3) }\end{array}$} & \multicolumn{1}{c}{ Middle site } & \multicolumn{1}{c|}{ NE site } \\
& \multicolumn{1}{c}{$(3)$} & \multicolumn{1}{c}{$(3)$} \\
\hline Pocillopora spp. & $48.9 \pm 2.50$ & $32.4 \pm 4.03$ & $61.9 \pm 0.68$ & $57.3 \pm 0.56$ \\
Acropora spp. & $3.9 \pm 0.33$ & $23.8 \pm 4.23$ & $17.1 \pm 1.47$ & $14.2 \pm 1.94$ \\
Porites spp. & $41.3 \pm 1.49$ & $16.5 \pm 4.02$ & $8.8 \pm 0.32$ & $14.6 \pm 1.06$ \\
Fungiids & $0.2 \pm 0.04$ & $2.9 \pm 0.98$ & $0.9 \pm 0.04$ & $1.8 \pm 0.22$ \\
Other & $6.0 \pm 0.42$ & $24.4 \pm 2.35$ & $11.4 \pm 0.42$ & $12.1 \pm 0.96$ \\
\hline
\end{tabular}

\section{Densities of zooxanthellae as a function of depth}

Coral colonies (4 randomly selected colonies of each species) selected for this part of the study showed some degree of bleaching. Analysis of tissue weights per surface area of skeleton (Table 4) revealed significant amounts of tissue left on the skeleton of each species. In all cases, however, the number of zooxanthellae was lower than that reported for healthy coral tissue $\left(1\right.$ to $5 \times 10^{6}$ cell $\mathrm{cm}^{-2}$; Drew 1972). The number of zooxanthellae per unit area also varied significantly as a function of depth and species ( $p<$ 0.06 ; Fig. 7). Whereas the number of zooxanthellae per unit coral surface area or weight in Pocillopora verrucosa did not vary between depths (Fig. 7A), the number of zooxanthellae in the 2 Acropora species ( $A$. samoensis and $A$. subulata) was higher at the deeper sites (Fig. 7B, C) 
A NW site (mean $=39.57 \pm 7.123)$

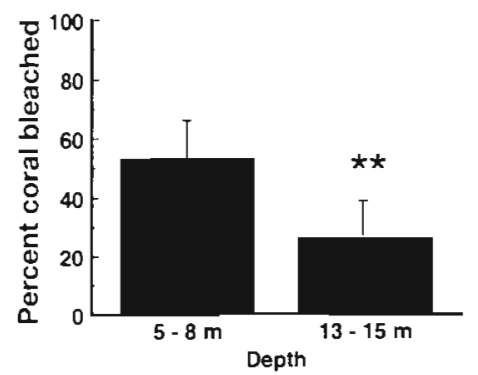

B Middle site $($ mean $=67.05 \pm 12.681)$

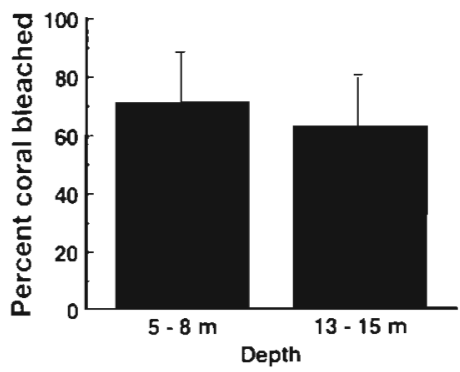

C NE site $($ mean $=72.38 \pm 7.108)$

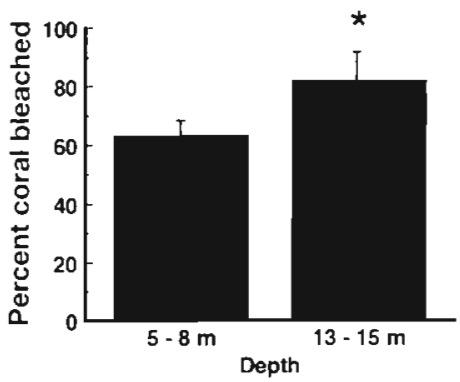

Fig. 4. Percentage of coral colonies affected by bleaching at 3 sites on the outer reef slope along the north coast of Moorea. Shown are means and standard errors of the mean (SEM) for 2 depths ( $\mathrm{n}=9$ quadrats of $3 \mathrm{~m}^{2}$ ). Significant differences detected: $p<0.05, \cdots p<0.01$. Overall means and SEM are also reported for data pooled for each site

\section{DISCUSSION AND CONCLUSIONS}

The results of this study confirm the reports of a major mass-bleaching event in French Polynesia in April 1994. Reports of mass-bleaching on a scale similar to that in French Polynesia (e.g. Cook Islands, American and Western Samoal indicate that massbleaching was probably in progress in a wide area of the Central and Western Pacific. The unusually high sea temperatures for this location $\left(1^{\circ} \mathrm{C}\right.$ higher, Fig. 2B; Climate Diagnostics Bulletin, January to April editions; see also Goreau \& Hayes 1994) are also strongly indicative that elevated water tempera-
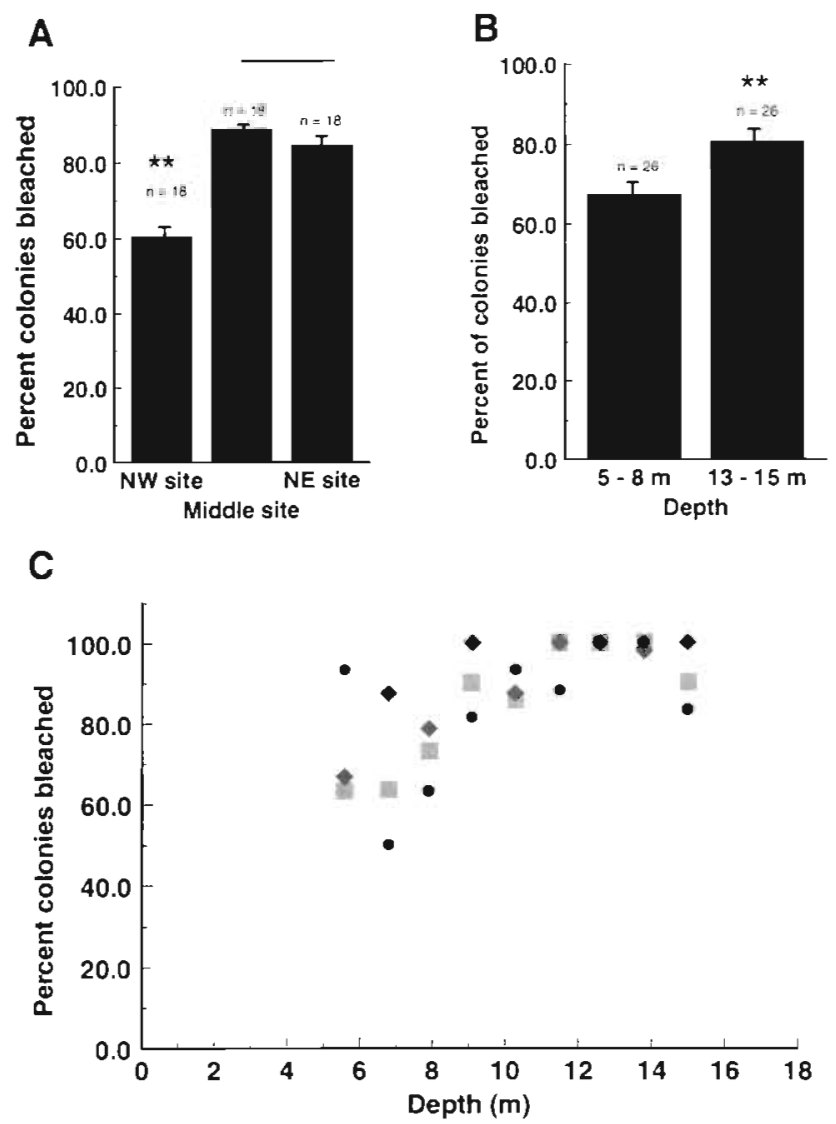

Fig. 5. Percentage of Pocillopora colonies ( $P$. eydouxi, $P$. verrucosa) either partly or completely bleached as a function of (A) site and (B) depth. Significant differences indicated by $\cdots(p<0.01)$. Lines connect samples that are not statistically different. Shown are means and standard errors of the mean. Data from the NE site are shown in (C). Different symbols in

(C) represent data from different transects at this site

tures are at least partly responsible for the current mass-bleaching affecting this region of the Pacific Ocean. This observation is confirmed by the low numbers of zooxanthellae (less than $0.5 \times 10^{6}$ cells $\mathrm{cm}^{-2}, 50 \times 10^{6}$ cells $\mathrm{g}^{-1}$ wet wt or $400 \times 10^{6}$ cells $\mathrm{g}^{-1}$

Table 2. Percentage of coral colonies either normal, bleached, or dead along 4 transects at Site D (14 to $15 \mathrm{~m}$ depth) on the outer reef slope of the north coast of Moorea. Shown are mean and standard errors of the mean

\begin{tabular}{|lccc|}
\hline & Normal & $\begin{array}{c}\text { Bleached } \\
\text { (partly or complete) }\end{array}$ & Dead \\
& \multicolumn{3}{c}{. } \\
\hline Pocillopora spp. & $67.9 \pm 4.92$ & $32.1 \pm 4.92$ & 0 \\
Acropora spp. & $5.4 \pm 2.50$ & $94.2 \pm 2.52$ & $0.4 \pm 0.43$ \\
Porites spp. & $91.0 \pm 3.67$ & $9.04 \pm 3.67$ & 0 \\
Fungiids & $53.2 \pm 10.56$ & $46.8 \pm 10.56$ & 0 \\
Other & $52.2 \pm 7.76$ & $47.3 \pm 7.43$ & $0.5 \pm 0.46$ \\
\hline
\end{tabular}


A Pocillopora spp.

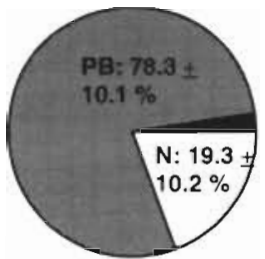

B Acropora spp.
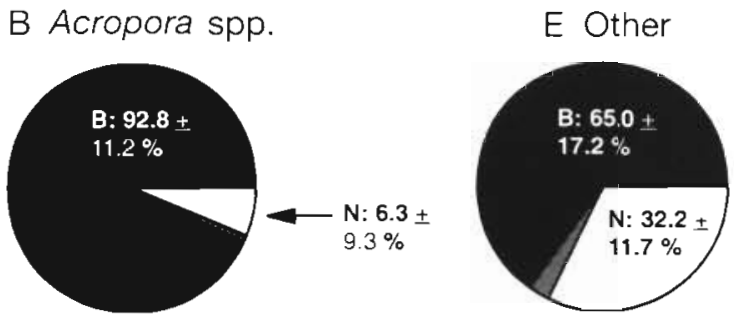

C Porites spp.

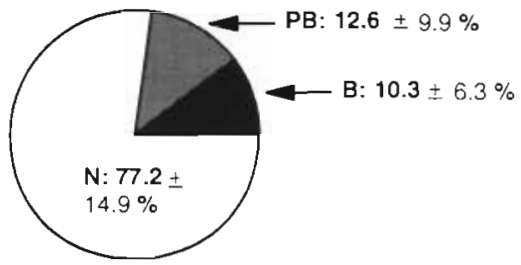

Fig. 6. Proportion of bleachect (B), partly bleached (PB) and normal-looking $(\mathrm{N})$ colonies among 5 types of reef-building corals from outer slope communties along the north coast of Moorea. Shown are the overall means for all 3 sites (values reported where greater than $5 \%$ )

Table 3. Percentage of coral colonies partly or completely bleached. $n=3$ transects; shown are mean and standard error of the mean

\begin{tabular}{|lccc|}
\hline & $\begin{array}{c}\text { Pocillopora } \\
\text { spp. }\end{array}$ & $\begin{array}{c}\text { Acropora } \\
\text { spp. }\end{array}$ & $\begin{array}{c}\text { Porites } \\
\text { spp. }\end{array}$ \\
\hline NW site & $73.9 \pm 13.28$ & $100 \pm 0$ & $12.9 \pm 10.95$ \\
Middle site & $92.1 \pm 4.54$ & $89.0 \pm 9.86$ & $42.5 \pm 21.64$ \\
NE site & $88.7 \pm 9.59$ & $98.2 \pm 5.55$ & $17.2 \pm 17.16$ \\
\hline
\end{tabular}

Table 4. Weight of tissue per surface area of coral colony for Pocillopora verrucosa, Acropora samoensis and A. subulata. $\mathrm{n}=4$ colonies; shown are mean and standard error of the mean

\begin{tabular}{|lccc|}
\hline & P. verrucosa & A. samoensis & A. subulata \\
\hline $\begin{array}{l}\text { Wet wt } \\
\left(\mathrm{mg} \mathrm{cm}^{-2}\right)\end{array}$ & $8.8 \pm 0.65$ & $15.0 \pm 1.41$ & $4.3 \pm 0.63$ \\
$\begin{array}{l}\text { Dry wt } \\
(\mathrm{mg} \mathrm{cm}\end{array}$ & $1.5 \pm 0.23$ & $2.1 \pm 0.34$ & $0.8 \pm 0.14$ \\
$\begin{array}{l}\text { Dry/wet wt } \\
\text { ratio }\end{array}$ & 5.87 & 7.69 & 5.17 \\
\hline
\end{tabular}

\section{Zooxanthellae per surface area}

\section{Zooxanthellae per wet weight}

A Pocillopora verrucosa
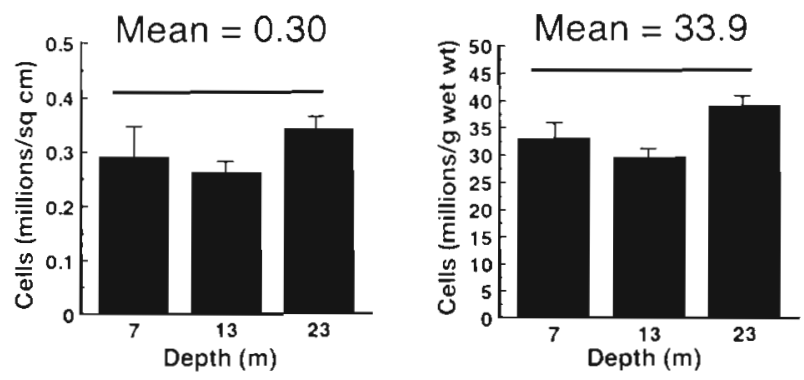

B Acropora samoensis
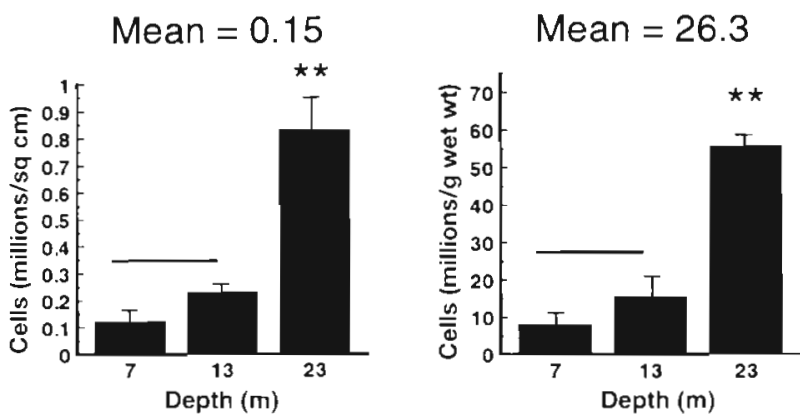

\section{Acropora subulata}
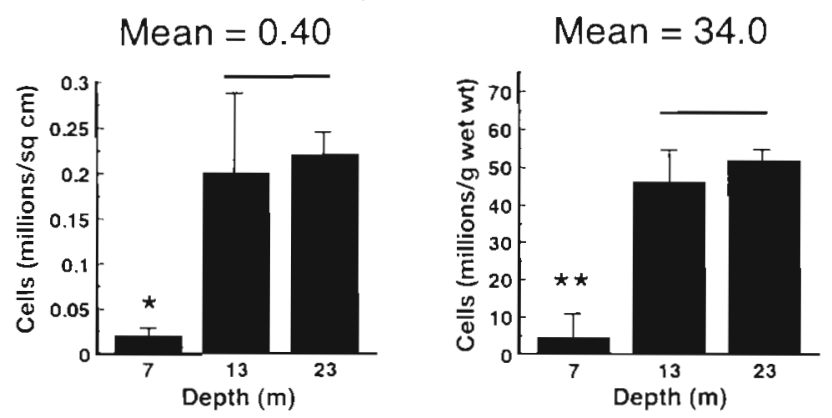

Fig. 7. Density of zooxanthellae per area and per wet wt, in colonies $(n=4)$ of 3 species from 3 depths off the outer reef slope, north coast of Moorea. Shown are means and standard errors of the mean. Significant differences indicated by $\cdots(p<$ $0.01)$ or ${ }^{*}(p<0.05)$. Lines connect samples that are not statistically different

dry wt) in the tissues of Pocillopora verrucosa, Acropora samoensis and $A$. subulata. These values also fall well below the range reported for normal, unbleached corals (1 to $5 \times 10^{6}$ cells cm$^{-2}$; Drew 1972) and are densities of zooxanthellae that have previously been associated with the effects of elevated temperature stress (Hoegh-Guldberg \& Smith 1989, Glynn \& D'Croz 1990). 


\section{Extent of mass-bleaching along the outer reef slope}

Between 39.57 and $72.38 \%$ of the live coral colonies were either partly or completely bleached along the outer reef slope of the north coast of Moorea. The extent of bleaching varied with depth, being significantly greater at shallow depths at one site (NW site), while being significantly greater at depth at another site (NE site). The difference between sites in the total amount of bleaching and the trend with depth is in part due to the different species composition along the outer reef slope of Moorea. While colonies of Acropora spp. numbered only approximately 20 (per $90 \mathrm{~m}^{2}$ transect) at the NW site, close to 100 Acropora spp. colonies (per $90 \mathrm{~m}^{2}$ transect) were present at the Middle and NE sites (Fig. 3). Conversely, Porites spp., a group of species that appears relatively resistant to bleaching (Fig. 6C; see also Salvat 1991, Gleason 1993), is also at least twice as abundant at the NW site as compared to the other 2 sites. The lower numbers of susceptible species (e.g. Acropora spp.) and increased numbers of tolerant species (e.g. Porites spp.) probably combine to give the observed differences between sites along the outer reef slope of Moorea. It is important to indicate that some differences between sites could be traced to differences in the response within a particular coral type. Pocillopora spp. showed lower overall bleaching at the NW site $(73.9 \pm 13.28 \%)$ relative to the other sites (Middle site: $88.7 \pm 9.59 \%$; NE site: $92.1 \pm 4.54 \%$ ). This effect was slight, however, compared to the larger differences accountable for by the different proportions of coral types that had vastly different susceptibilities to bleaching.

\section{Species-dependent susceptibility to bleaching}

The order of susceptibility to bleaching reported by Salvat (1991) and Gleason (1993) (Acropora spp., Pocillopora spp., Porites spp.) was confirmed in the present study. This sequence also appears to support the suggestion that coral genera with fast growth rates and high metabolic rates are the most susceptible to bleaching (e.g. Acropora, Pocillopora versus Porites; Glynn 1993). The differences in susceptibility between species also suggest the potential for the development of indices (based on the extent to which particular genera are affected) for monitoring the severity of a massbleaching event. Although interpretation of similarities and differences between mass-bleaching events should be done cautiously (i.e. taking into account differences between observers and biogeographical considerations), it does suggest a possible device to monitor and compare the severity of mass-bleaching events (e.g. events with bleached Acropora spp. only would indicate milder events than those with Porites spp. as well). All available evidence, for example, points to the fact that the current mass-bleaching event is at least equal in magnitude to the mass-bleaching event that occurred across French Polynesia in 1991. For example, Salvat (1991) reported a similar proportion of Acropora spp. (97.8\% of Acropora spp.; Salvat 1991) as being bleached on the outer slope communities of Moorea. This was confirmed by Gleason (1993) who reported 95 and $90 \%$ of Acropora spp. bleached on the outer reef slope and back reef respectively. Other similarities abound: the 1991 bleaching occurred at the same time (February to April) and involved the same sequence of susceptibilities, with Acropora spp. being the most affected and Porites spp. being the least affected.

\section{Predicted mortality and community impacts}

Only 2 dead Acropora spp. colonies were found at Site D in April $45 \mathrm{~d}$ after the advent of bleaching on a massive scale (Table 2). This low mortality at the beginning of a bleaching event agrees well with mortality estimates observed in April 1991 (Salvat unpubl.). Based on the eventual mortality of the 1991 bleaching event (Salvat 1991), 20\% of the corals making up the outer slope community will die by the end of August 1994. The great differences in the mortality of particular coral taxa following bleaching (e.g. Acropora spp. > Pocillopora spp. > Porites spp.; Salvat 1991, Gleason 1993) indicates that some coral species will experience far greater impacts. Only $10 \%$ of bleached Acropora spp., for example, recovered during the 1991 mass-bleaching event while all colonies of bleached Porites spp. recovered (Gleason 1993). A similar proportion of the Acropora spp. bleached during the current bleaching event are expected to survive

Given the quite striking differences in the susceptibility and mortality between species, mass-bleaching events have the potential to change the structure of coral communities towards those dominated by more tolerant species such as Porites spp. (Gleason 1993). How (and indeed if) reef communities change given the impact of regular mass-bleaching events is still the subject of much speculation (Glynn 1991, 1993). However, the increased frequency $(1983,1987,1991,1994)$ and severity of recent mass-bleaching events might be expected to favour some coral genera over others in ways that are not simply related to temperature tolerance. Pocillopora spp., for example, are reproductively mature in half the time of Acropora spp. (1 to 2 versus 4 to $5 \mathrm{yr}_{\text {; }}$ Harrison \& Wallace 1990), and hence would be predicted to reach reproductive maturity in between mass-bleaching events while Acropora spp. 
would not. Other factors such as reef connectivity and larval supply are also likely to play key roles in determining the extent to which particular reefs may remain impoverished following mass-bleaching. Although the precise impact of mass-bleaching has yet to be determined, it is important to point out that there are some examples of species (e.g. hydrocoral Millepora boschmai) that already appear to have come close to being globally extinct in the face of repeated massbleaching events (Glynn \& de Weerdt 1991, Glynn \& Feingold 1992).

\section{Mass-bleaching, water temperature and global warming: possible connections}

An important highlight of the present study is the continuous temperature data measured in situ before, during and after the advent of the 1994 mass bleaching, which (to the knowledge of the authors) is the first time data of this nature have been collected. Water temperatures during the first half of 1994 were unusually high (Fig. 2A), ranging up to a degree higher than those of 1992 and 1993 (Fig. 2A). Bleaching did not occur on a massive scale in 1992 or 1993 (Salvat unpubl.). Significantly, in situ temperatures were higher than $29^{\circ} \mathrm{C}$ for 3 mo in 1994 , but did not increase above $29^{\circ} \mathrm{C}$ in 1992 or 1993. Corals from a similar thermal regime (e.g. Lizard Island, Great Barrier Reef) bleached at temperatures above $29^{\circ} \mathrm{C}$ (Hoegh-Guldberg \& Smith 1989). SST from the NOAA satellite data also confirm the conclusions from the in situ monitoring project and further strengthen the suggestion that subtle temperature increases $\left(+1^{\circ} \mathrm{C}\right)$ over 2 to $4 \mathrm{wk}$ can have substantial influences over the health of hermatypic coral and other invertebrate symbioses.

While a good connection between warmer than usual sea temperatures and mass-bleaching has been established, the connection between global climate change (Glynn 1993, Goreau \& Hayes 1994) and the recent spate of unusually high sea temperatures is beyond the confines of this study. However, it is becoming increasingly apparent that small increases in sea temperature have potentially major consequences for coral reef ecosystems. Given the temperature increases predicted in an unrestrained global warming scenario $\left(1\right.$ to $5^{\circ} \mathrm{C}$ by the year 2100 ; Intergovernmental Panel on Climate Change, in Wigley \& Raper 1992), it is clear that coral reefs may be the first ecosystems to register a response to global climate change. The study of the changes to coral reef ecosystems in the face of regular mass-bleaching events, though in its infancy, must be a priority of future research efforts into understanding the ramifications of global climate change.
Acknowledgements. Many people were instrumental in making this investigation and subsequent report on the latest incident of mass-bleaching possible. The authors are grateful to Greenpeace International for providing funding for this study The work done by B.S. was done under the auspices and the support of the Ministère de l'Environnement, SRETIE, Paris. and the Foundation Naturalia Polynesia. They also thank Paulina Selvakumaraswamy and Sophie Dove (laboratory analysis, graphics preparation); Lyn Goldsworthy, Stephanie Mills and Elisabeth Mealy (logistics); Frank Murphy (station manager, diving and boating assistance), Roger Grace (transect photography), Peter Thompson (photography); J. E. N Veron (coral identification), Yannuck Chancerelle (diving) Scott Herring, Misaki Takabayashi, Ambariyanto and Anthony Baker (laboratory assistance). This is contribution no. 36 from the Gump Biological Station, Moorea, where part of this work was done.

\section{LITERATURE CITED}

Atwood DK, Hendee JC, Mendez A (1992) An assessment of global warming stress on Caribbean coral reef ecosystems. Bull mar Sci 51:118-130

Brown BE, Suharsono (1990) Damage and recovery of corals reefs affected by El Niño related seawater warming in the Thousand Islands, Indonesia. Coral Reefs $8: 163-170$

Coffroth MA, Lasker HR, Oliver JK (1990) Global ecological consequences of the 1982-83 El Niño-Southern Oscillation. In: Glynn PW (ed) Elsevier Oceanography Series, Elsevier, Amsterdam, p 1-14

Coles SL, Jokie] PL (1978) Synergistic effects of temperature, salinity and light on the hermatypic coral Montipora verrucosa. Mar Biol 49:187-195

Drew EA (1972) The biology and physiology of algal-invertebrate symbiosis. II. The density of algal cells in a number of hermatypic hard corals and alcyonarians from various depths. J exp mar Biol Ecol 9:71-75

Gates RD (1990) Seawater and sublethal coral bleaching in Jamaica. Coral Reefs 8:193-197

Gates RD, Baghdasarian G, Muscatine L (1992) Temperature stress causes host cell detachment in symbiotic cnidarians: implications for coral bleaching. Biol Bull 182: 324-332

Gleason DF, Wellington GM (1993) Ultraviolet radiation induces coral bleaching: evidence from field experiments. Nature 265:836-837

Gleason MG (1993) Effects of disturbance on coral communities: bleaching in Moorea, French Polynesia. Coral Reefs 12:193-201

Glynn PW (1984) Widespread coral mortality and the 1982-83 El Niño warming event. Environ Conserv 11:133-146

Glynn PW (1988) El Niño-Southern Oscillation 1982-1983: nearshore population, community, and ecosystem responses. A Rev Ecol Syst 19:309-345

Glynn PW (1991) Coral reef bleaching in the 1980 s and possible connections to global warming. Trends Ecol Evol 6 : $175-179$

Glynn PW (1993) Coral reef bleaching: ecological perspectives. Coral Reefs 12:1-17

Glynn PW, Colgan MW (1992) Sporadic disturbances in fluctuating coral reef environments: El Niño and coral reef development in the Eastern Pacific. Am Zool 32 $707-718$

Glynn PW, D'Croz L (1990) Experimental evidence for high temperature stress as the cause of the EI Niño - coincident coral mortality. Coral Reefs 8:181-191 
Glynn PW, de Weerdt WH (1991) Elimination of two reefbuilding hydrocorals following the 1982-83 El Niño warming event. Science 253:69-71

Glynn PW, Feingold JS (1992) Hydrocoral species is not extinct. Science 257:1.845

Glynn PW, Imai R, Sakai K, Nakano Y, Yamazato K (1993) Experimental responses of Okinawan (Ryukyu Islands, Japan) reef corals to high sea temperatures and UV radiation. In: Richmond RH (ed) Proc 7 th Int Coral Reef Symp, Guam, Vol 1. Abstracts. Univ of Guam Press, Mangilao, p $27-37$

Goreau TJ (1992) Bleaching and reef community change in Jamaica: 1951-1991. Am Zool 32:683-695

Goreau TJ, Hayes RL (1994) Coral bleaching and ocean 'hot spots'. Ambio 23:176-180

Harriot VJ (1985) Mortality rates of scleractinian corals before and during a mass bleaching event. Mar Ecol Prog Ser 21:81-88

Harrison PL, Wallace CC (1990) Reproduction, dispersal and recruitment of scleractinian corals. In: Dubinsky $Z$ (ed) Coral reefs. Elsevier Science Publishers, Amsterdam, $p$ 133-206

Hayes RL, Bush PG (1990) Microscopic observations of recovery in the reef-building scleractinian coral Montastrea annularis, a coral bleaching on a Cayman reef. Coral Reefs $8: 203-209$

Hoegh-Guldberg O, McCloskey LR, Muscatine L (1987) Expulsion of zooxanthellae by symbiotic cnidarians from the Red Sea. Coral Reefs 5:201-204

Hoegh-Guldberg O, Smith GJ (1988) Physiological correlates of light and temperature stress in two pocilloporid corals. Proc Ass Is Mar Lab Carib 21:57

Hoegh-Guldberg O, Smith GJ (1989) The effect of sudden changes in temperature, irradiance and salinity on the population density and export of zooxanthellae from the reef corals Stylophora pistillata (Esper 1797) and Seriatopora hystrix (Dana 1846). J exp mar Biol Ecol 129:279-303

Jokiel PL, Coles SL (1974) Effects of heated effluent on hermatypic corals at Kahe Point, Oahu. Pacif Sci 28:1-18

Jokiel PL, Coles SL (1977) Effects of temperature on the mortality and growth of Hawaiian reef corals. Mar Biol 43: $201-208$

This article was presented by A. J. Underwood (Senior Editorial Advisor), Sydney, Australia
Lasker HR, Peters EC, Coffroth MA (1984) Bleaching of reef coelenterates in the San Blas Islands, Panama. Coral Reefs $3: 183-190$

Lesser MP, Stochaj WR, Tapley DW, Shick JM (1990) Physiological mechanisms of bleaching in coral reef anthozoans: effects of irradiance, ultraviolet radiation and temperature on the activities of protective enzymes against active oxygen. Coral Reefs 8:225-232

Marsh JA (1970) Primary productivity of reef-building calcareous red algae. Ecology 51:255-263

Oliver J (1985) Recurrent seasonal bleaching and mortality of corals on the Great Barrier Reef. Proc 5th Int Coral Reef Congr 4:201-206

Reese CJ, Kleppel GS, Dodge RE (1988) The physiological implications of bleaching of corals off southeast Florida Proc Ass Is Mar Lab Carib 21:66

Roberts L (1987) Coral bleaching threatens Atlantic reefs Science 238:1228-1229

Roberts L (1988) Corals remain baffling. Science 239:14

Salvat B (1991) Blanchissement et mortalité des scléractiniaires sur les récifs de Mooréa (archipel de la Société) en 1991. Cr Acad Sci Paris 314:105-111

Salvat B (1992a) Coral reefs - a challenging ecosystem for human societies. Global environ Change 2:12-18

Salvat B (1992b) The 1991 bleaching event in the Society Islands, French Polynesia. In: Richmond RH (ed) Proc 7 th Int Coral Reef Symp, Guam, Vol 1. Abstracts. Univ of Guam Press, Mangilao, p 73

Sebens KP (1994) Biodiversity of coral reefs: what are we losing and why? Am Zool 34:115-133

Vaughan TW (1914) Reef corals of the Bahamas and of southern Florida. Yb Carnegie Inst Washington 13:222-226

Wigley TML, Raper SCB (1992) Implications for climate and sea level of revised IPCC emissions scenarios. Nature 357 293-300

Williams EH, Bunkley-Williams L (1990) The world-wide coral bleaching cycle and related sources of coral mortality. Atoll Res Bull 335:1-71

Yonge CM, Nichols AG (1931) Studies on the physiology of corals. $V$. The effect starvation in light and in darkness on the relationship between corals and zooxanthellae. Sci Reps Great Barrier Reef Exped 1(7):177-211

Manuscript first received: August 25, 1994

Revised version accepted: January 3, 1995 